\title{
Three Phases of the Theatrical Public Sphere in Estonian Theatre
}

\section{EVA-LIISA LINDER}

\begin{abstract}
The concept of the public sphere by Jürgen Habermas has inspired humanities and theatre studies. Estonia, as a small post-totalitarian nation state, proves the concept especially relevant as its recent history reveals three different phases of the theatrical public sphere. 1) Theatre as a secret forum. In Soviet times, theatre served as a political and ideological tool, providing a place for keeping the national memory and consolidating society. 2) The active and technical use of the public sphere by newly awakened political theatre NO99 since 2005. 3) The agonistic theatrical public sphere. During the past decade, a whole wave of projects have discussed national identity with concurrent antagonisms: globalization vs nationalism, civic vs ethnic nationalism, the Estonian vs Russianspeaking community. Theatre has commented on two concepts of national identity, e-Estonia and Organic Estonia, innovative digitalization and cultural traditions. The discursive public sphere has led to increased civic awareness and structural changes in the developing democracy, supported integration, and anti-xenophobia in Estonia. At the same time, two main characteristics of the theatrical public sphere have been highlighted: spatiality and political relevance.
\end{abstract}

\section{KEYWORDS}

public sphere, political theatre, critical theory, national identity, Estonian theatre

ISSN 2002-3898

(C) Eva-Liisa Linder and Nordic Theatre Studies

PEER REVIEWED ARTICLE Open access: https://tidsskrift.dk/nts/index

Published with support from Nordic Board for Periodicals in the Humanities

and Social Sciences (NOP-HS)

DOI: 10.7146/nts.v31i1.113002 


\section{Three Phases of the Theatrical Public Sphere in Estonian Theatre}

Revolutions in Eastern Europe have made the concept of the public sphere topical, declared Jürgen Habermas in his foreword to the Structural Transformation of the Public Sphere in 1990. The changing political situation reopened the possibility for his theory to make an input into addressing questions about democracy. ${ }^{1}$

The experience of the Baltic states has confirmed this assumption multiple times. The public sphere became a cornerstone for the new democratic societies. However, if we widen the scope to the theatrical public sphere, we can detect even more of its manifestations as it functioned long before the revolutions. All examples of theatrical public sphere, regardless of their social context, have enabled protest and opposition to the ruling mentalities and supported democratic developments.

Estonia is a good example, as coming from a totalitarian regime, it has demonstrated democratic and economic development which has granted the country a reputation as the tiniest, but most successful of the Baltic states. Moreover, Estonia enjoys an exceptionally high number of theatre attendances. For a nation of 1.3 million citizens, there were 1.2 million attendances in 2016. Theatre performances and concerts are the most popular forms of culture, and about $45 \%$ of people go to the theatre at least once a year, according to a recent study. ${ }^{2}$ Theatre scholar Janelle Reinelt has found the statistics of Estonia telling as it confirms that theatre as a cultural institution is a potential locus for a meaningful rethinking of national issues and that the public sphere is more potent in small countries. ${ }^{3}$

However, Estonian sociologist Marju Lauristin has voiced her longing for a more elevated role for culture in solving social problems as the potential of the arts has been underestimated in Estonia. It takes more than rational economic development for a nation-state to function, otherwise the citizens could just as well anonymously belong to any global network. ${ }^{4}$

\footnotetext{
1 Habermas 1990, 11-12.

2 Kivirähk 2016, 3-4.

3 Reinelt 2005, 371.

4 Lauristin 2011, 197.
} 
The necessity of a mediating zone between the state and individuals has been justified by philosophers many times. After the terrorist attacks of September 11, 2001, Habermas stated that the spiral of violence begins with a spiral of distorted communication. ${ }^{5}$ Chantal Mouffe agrees: "When institutional channels do not exist for antagonisms to be expressed in an agonistic way, they are likely to explode in violence."6

Theatre scholars Christopher B. Balme ${ }^{7}$ and Janelle Reinelt ${ }^{8}$ state that any considerations of the public sphere should start with the definition by Habermas as a discursive arena where individuals can come together to freely discuss societal problems and through that discussion influence political actions. ${ }^{9}$ However, the remarks by Balme and Reinelt are crucial for elaborating the concept for theatre. While Habermas sees the public sphere as a discursive space, containing rational debate and aiming at consensus, Reinelt makes two additional comments. Firstly, affective and emotive communication should be included. Secondly, the print culture should be complemented by the role of orality, visuality, and other channels of communication. ${ }^{10}$ Reinelt admits that embodied practices may involve political positions and contribute to the multiplicity of polyvocal opinions circulating in the public sphere. ${ }^{11}$

Balme agrees with Reinelt's suggestions and, taking inspiration from the agonistic concept of Chantal Mouffe, concludes that the theatrical public sphere should include the discursive potential of the Habermasian theory, but should also be augmented by the agonistic and ludic dimensions. Balme outlines the completed vision as a dialectical resolution of two apparently opposing views: the extended concept of agonism with its emphasis on emotion and affect, without forgoing more rational-critical modes of dispute. ${ }^{12}$

Taking these arguments into account, the present paper will focus on three different manifestations of the theatrical public sphere in Estonian theatre during the past decades. Although the bulk of the repertoire still belongs through its aim, topics, and structure to the private sphere, certain discussion zones stand out in historical and contemporary practices, which give insight into different phases of the theatrical public sphere.

1) Theatre as the secret forum behind the Iron Curtain during the Soviet occupation from 1940 to 1990 . Although the period saw many subspheres, their overall structure was defined by the totalitarian political regime. As the experience in Estonia reflects the fate of other East European countries under totalitarian rule, the phase will be discussed briefly.

2) Political theatre activating the public sphere: the active and technical demonstration of the public sphere by Theatre NO99 (2005-2018). The projects by NO99 addressed various political issues, aiming at public discussion

5 Habermas 2001.

6 Mouffe 2013, 122.

7 Balme 2012, Balme 2014, 2.

8 Reinelt 2011, 17.

9 Habermas 1990, 292.

10 Reinelt 2011, 18.

11 Reinelt 2011, 16, 18-19.

12 Balme 2014, 11. 
by novel means: huge political spectacles, media coverage, PR campaigns, artist talks, publishing metatexts, etc. NO99 was the main company that succeeded in moving the debate from the aesthetic realm of theatre into the wider public sphere of political debate.

3) The agonistic theatrical public sphere. Over the past decade, different companies have discussed national identity with concurrent antagonisms: globalization vs nationalism, civic vs ethnic nationalism, the Estonian vs Russianspeaking communities. A whole wave of projects have reflected mentalities in a changing Europe: from conservative nationalism to anti-xenophobia. Here, the discursive theatrical public sphere proves to be a fruitful umbrella concept, explaining the dynamics of changing attitudes in the longer run. Semiotics and critical theory support the analysis of different productions.

The three phases, that cover more than seventy years of history, witness features of the three types of public sphere described by Habermas and Balme: a) the representative form of the public sphere typical of absolutist political regimes, b) the bourgeois public sphere with its universal access and equality of status, and c) the new trend towards performative intervention, introduced by Balme. ${ }^{13}$

In doing so, two main characteristics of the theatrical public sphere have been highlighted: spatiality and political relevance. While Habermas named theatre as a place for the emerging bourgeois public sphere in the eighteenth century, theatre houses in contemporary Estonia prove themselves to be the most fertile public spaces for discursive practices before they enter the political scene proper.

\section{1) The secret forum: the theatrical public sphere behind the Iron Curtain}

Sharing the fate of all Baltic states, Estonia was occupied and annexed by the Soviet Union in 1940 and spent the next fifty years under totalitarian rule. The occupation resulted in mass deportations, arrests, and repressions. 33,000 Estonians were deported to Siberia, ${ }^{14}$ while the country was overwhelmed by an Orwellian dystopia.

It means that during roughly half its history, professional Estonian theatre had to function under the conditions of imperialism, the most terrible form of the ratio, as stated by Adorno and Horkheimer. ${ }^{15}$ The totalitarian regime meant constant censorship that, in Balme's view, implies a deep conviction about the political potency of the theatrical gathering. ${ }^{16}$ Theatre as a public domain remained under tighter official supervision than the other arts. The repertoire was ruled by social realism, the only artistic style accepted. Within the system, plays needed a licence in order to be premiered. State officials sat in the audience and checked that no improvisational words nor intonations slipped from the actors' lips. Even an accidental combination of the blue, black, and white colours of the Estonian national flag in costumes or set design would have caused difficulties.

However, by the 1950s, playwrights and theatres were ready to take risks

13 Balme 2012.

14 Rähesoo 2008, 55.

15 Adorno, Horkheimer 2016, 89.

16 Balme 2014, 16. 
and audiences quickly learned the culture of hints and allusions. ${ }^{17}$ Although the 1960s gave more breathing space, enabling the rise of theatre renewal with physical and ritual theatre, the control was tightened again in the 1970s and 1980s. At the same time, the opposition to officialdom gave the arts throughout these decades a clear social function. ${ }^{18}$ Estonian theatre scholar Luule Epner has pointed out that theatre operated as a memory machine..$^{19}$ National values and myths served to consolidate society, confirming the formula: the lesser the political and economic freedom, the greater the need for unifying cultural events. ${ }^{20}$ The phenomenon can be seen in the wider scope of international analyses by Stephen Wilmer, indicating that particularly at times of national crisis, the theatre has served as a political and ideological tool to help configure the nation. ${ }^{21}$

\section{2) N099 demonstrating theatre as the new political force}

It took a long time for political theatre to recover in post-totalitarian countries that reestablished their democratic societies. After the Singing Revolution and Estonia's restoration of independence in 1991, theatre as a form of public art had to reconstruct its role. ${ }^{22}$

Theatre NO99 started off as the first company actively producing socially relevant performances since 2005 . Founded by the artistic tandem of stage director Tiit Ojasoo and interdisciplinary artist Ene-Liis Semper, and only ten actors, the company turned its "thorn of criticism" 23 towards the audience and politicians, giving rise to the audience-critical turn in Estonian theatre. The style of NO99 corresponds to what Hans-Thies Lehmann describes as post-Brechtian ${ }^{24}$ and post-theatrical theatre, ${ }^{25}$ emphasizing the enlightening function of theatre in these concepts. NO99 has demonstrated the dimensions and opportunities of the public sphere in their projects on various issues like racism, nationalism, the energy crisis, the falling birth rate, etc., but most eminently in its research into the mechanisms of power.

NO99 tested society's limits of tolerance many times. ${ }^{26}$ Some examples. In 2009, their piece of devised theatre, How to Explain Pictures to a Dead Hare, took inspiration from the scandalous performance by German artist Joseph Beuys and introduced different fields of contemporary art, e.g. performances, modern dance, and installations, asking self-critically how to explain the works to audiences, officials, and sponsors. One of the central problems raised by the project was poor cultural funding. The action features a parody of Laine Jänes ('Jänes' meaning 'hare'), the then Minister of Culture. In various episodes,

17 Rähesoo 2008, 56, 63-64, 69.

18 Rähesoo 2008, 79-80.

19 Carlson 2001, 2.

20 Epner 2005, 379, 381, 384-385.

21 Wilmer 2002, 3.

22 Rähesoo 2008, 81.

23 Adorno 1997, 21.

24 Lehmann 2006, 33.

25 Lehmann 2007.

26 Two more projects by NO99, Hot Estonian Guys and Three Kingdoms, are covered in the next section. 
the Minister is shown engaged in dialogue with theatre practitioners who are repeatedly left disappointed after hearing there is no money for the theatre. In many scenes, the Minister is subjected to accidental attacks. In one, a dog, resembling the Kulik's dog (played by Risto Kübar), suddenly lunges at the Minister. In another, the Minister gets accidentally hit in the middle of a socalled national sports event, which includes a competition in "precision peeing." Afterwards, the Minister herself said that she liked the show and the issues raised by NO99 were vital. ${ }^{27}$ Thus, the project made headlines in newspapers, at the same time sending out a signal that sharp criticism is allowed in theatre.

It is worthy of note that NO99 with its leading figure Tiit Ojasoo, who could be called the Romeo Castellucci of Estonian theatre, was state-subsidized. The example serves as an exception to Janelle Reinelt's hypothesis that direct political efficacy is practically impossible within state-supported and subsidized theatres. ${ }^{28}$

In the following year, the fictive political movement Unified Estonia (2010), with its title hinting ironically at United Russia, Vladimir Putin's political party, became a prime example of political theatre in Estonia. The mock party announced that Saku Suurhall, the biggest indoor arena in Estonia, would be used as the venue for its "assembly", thereby highlighting the message that everyone was invited. With an attendance of more than 7,000, Unified Estonia Assembly became one of the largest theatre events in contemporary Europe. ${ }^{29}$

The aim of the project was, however, more ambitious: to engage the whole society while revealing the political misdeeds. During the 44 days of the project, NO99's actors played politicians in public, using the technique of subversive overidentification. ${ }^{30}$ The team made larger-than-life promises in TV and radio, put up political posters and launched adverts on TV, uploaded video lectures entitled Election School to YouTube, and used other means to X-ray the techniques of political manipulation: populism, demagogy, buying off voters, the propagandistic use of youth associations, etc. At the same time, the project aimed at changing "the serf mentality" of Estonian voters, criticized by Ojasoo in his final speech at the Assembly. ${ }^{31}$

The project was greeted with wide attention. The company has documented the making of Unified Estonia in their first film, a documentary entitled Ash and Money (available with English subtitles on YouTube). An exposition of Unified Estonia participated in the Prague Quadrennial of Performance Design and Space in 2015, winning the Golden Triga for the Best Exposition and for Innovative Approach to Performance Design. In Prague, the company summarised that the Unified Estonia project was unique in terms of its approach to actual political issues as it was never treated merely as theatre but as a real political force. Polls indicated that the new party created by NO99 would take $25 \%$ of the votes if they

27 Kase 2009.

28 Reinelt 2011, 21.

29 Unified Estonia Assembly 2018.

30 Wilmer 2013, Wilmer 2009.

31 Unified Estonia Assembly 2013. 
were to run in the parliamentary elections. ${ }^{32}$

While the huge political spectacle of the Assembly has been well covered by reviews, ${ }^{33}$ two one-off actions belonging to the same project seem telling from the point of view of the public sphere as well, although they have been practically overlooked. The first of the two, the Unified Estonia flash mob, invited people to the main square of the capital Tallinn, introducing the concept of flash mob to Estonian audiences. The aim was to sing Unified Estonia's anthem, and a few dozen fans made the action a success.

The other action, entitled When 200 will become 6500, also tested involving audiences and generating political dialogue. However, the outcome was unexpected. On NO99's small stage, actors enacted provocative episodes, e.g. inviting the audience to dance along or complain about the real estate development on the coastline blocking access to the sea, an irritating situation for the sealoving Estonians. "What do we say to that?" actors asked the audience, and commented ironically: "We see political power as a parent or a god, who takes decisions for us." An actress asked a volunteer to step on stage, but left her there alone, challenging the audience to come to support her. Soon, there were more people on stage than sitting in the audience. The situation grew tense as one of the persons remaining seated was Rein Lang, the then Minister of Justice. As actors asked him to join the crowd, the Minister answered with a question: "What is it that you have to say?" A provocative back-and-forth followed. The action was drowned in the unprepared discussion at this point. Only a slogan at the back of the stage carried on the line of thought, citing Estonian literary classic Friedebert Tuglas: "Estonia is a country where truth has been replaced by authority, freedom by fear, and yearning by bourgeois ennui." 34

The episode with the Minister made headlines in the media. Tiit Ojasoo, NO99's artistic director, claimed that the performance was interrupted by the Minister. The Minister in turn retorted by calling the allegations part of a smear campaign. Silver Meikar, a member of the Prime Minister's Reform Party, who had been in the audience, described the action in his blog as "a frightening and dangerous masterclass in crowd manipulation." He admitted that the borders between the stage and the auditorium, play and political propaganda were blurred. He warned the company not to cross the line - i.e. not to go into politics as there is no need for another failed political party. ${ }^{35}$

The success of the Unified Estonia project was proven during the following years, which saw a Reform Party politician - incidentally, Silver Meikar himself, influenced by the theatrical project - reveal illegal funding practices in the party. It was followed by public demonstrations and the launch of an independent political movement called Enough of Deceitful Politics, demanding honesty and transparency from the political establishment. Finally, the Minister of Justice, a central figure in the funding scandal, resigned in 2012. Therefore, NO99 used different techniques to activate the public sphere, which, in turn, led to an

32 Unified Estonia 2015.

33 Virro 2012, Pesti 2012, Linder 2013.

34 Radar 2015.

35 Eesti Ekspress 26.3.2010. 
increased civic awareness and structural changes in the developing democracy of Estonia.

During its fourteen years of activity, NO99 enjoyed the admiration of people interested in the arts, at the same time gathered political enemies. The Conservative People's Party of Estonia proposed depriving NO99 of its state subsidies. It claimed that instead of producing culture, NO99 perpetuated "radical left-wing propaganda, which is difficult to explain to the taxpayer in terms of necessity and aesthetic quality." ${ }^{36}$ Although the proposal was rejected by the Parliament, the critique continued, even after NO99 was awarded the Europe Theatre Prize for New Theatrical Realities in 2017, one of the most notable international recognitions given to an Estonian company. As the biblical saying goes, "A prophet is not without honour, save in his own country." 37

\section{3) Theatre as a collective echo chamber for social concerns on national identity}

After NO99 withdrew from its role as a watchdog of democracy in its last years, political theatre remained somewhat under represented in Estonia. However, there has been an issue sparking lively discussions over the past decade, and using theatre as "a collective echo chamber", as described by Balme ${ }^{38}$. This is national identity.

Although the issue has occasionally appeared in Estonian theatre since the time of national awakening in the nineteenth century, it was not until recently that theatre started to voice original opinions, to present authentic research and insights, and to provide creative solutions to topical problems. Two paradigm shifts can be detected behind this change: socially, the globalization trends and the migration crisis in Europe, and artistically, the rise of postdramatic theatre with a tendency to documentary, devised, and applied theatre.

Reconsidering national values from a contemporary perspective has become a new challenge for many theatre companies, supported by theatre's ludic power, ${ }^{39}$ which makes it possible to easily deconstruct and reconstruct fictional worlds. ${ }^{40}$ Theatre serves here as a public space bringing together different cultures and communities, challenging the boundaries, estrangement, and xenophobia rooted in society. In audience discussions, social research carried out by theatre companies surpasses that by the media in its scope and depth.

The discussion revolving around national identity has mainly addressed three questions: a) how to react to a changing Europe: nationalism or globalization, civic or ethnic nationalism?, b) how to integrate the Russian-speaking community

36 Reisenbuk 2017.

37 On 31 October 2018, NO99 issued a press release declaring their joint decision to end the company's activities (Theatre NO99 2018). Although the end was written into the theatre's initial concept of countdown from 99, they stopped at production NO30. They explained it as being due to their inability to follow their creative ideals. Critics have also seen here their tendency to follow Samurai ethics (Pilv 2019). The Conservative People's Party, on the other hand, declared the end of the theatre as a political achievement for their party (Põld 2018).

38 Balme 2014, ix.

39 Balme 2014, 12.

40 Epner 2005, 379, 385, 400. 
in Estonia?, c) which identity model suits the country best, e-Estonia or Organic Estonia?

The following overview offers an insight into the debate that has increased recently, forming a whole wave of productions on national issues that revolve around three antagonisms.

\section{1) Nationalism vs globalization}

The topic of demographic crisis and conservative nationalism was first addressed in Hot Estonian Guys by NO99 (2007). The introductory text of the theatrical research project declared: "It is not a question of if, but when the extinction of Estonians will take place." The promotional campaign covered the capital with posters: "Men, start making babies."

According to the storyline, an extraordinary situation called for extraordinary measures: a group of Estonian men founded a club with the sole aim of making as many babies as possible. Their action is morally unacceptable, ethically unsound, but still the only one to produce results. ${ }^{41}$ Although the design of the production was replete with national symbols - national costumes, songs, and dances, to an extent reminiscent of the famous Estonian Song Festivals -, the content dealt with rather more realistic issues: the financial difficulties of the hot Estonian guys, their communication problems with Russian PR-workers, their undertaking from the viewpoint of women, etc. The project encouraged a wide debate in the media. Urve Eslas, a journalist at the daily Postimees, asked whether the aims of a state can be turned into personal imperatives: are women obliged to simultaneously serve as loyal workers, consumers, and birth-givers? ${ }^{42}$

Surprisingly, a small non-professional troupe of young Seto women took the lead in tackling national issues next. Their piece of applied theatre, How to Sell a Seto? (Youth Studio of Taarka Heritage Theatre, 2012) with the self-ironic title, was played on the sand floor of a barn in Setomaa. It is a region in the southeast corner of Estonia, where Eastern and Western civilizations meet, inhabited by indigenous ethnic and linguistic minority Setos for more than 8000 years. The Setos still keep alive their customs and a unique multiple-voice singing tradition called leelo, added to the list of UNESCO's Intangible Cultural Heritage.

However, the present-day situation of young Setos is complicated. On the one hand, the new generation is expected to keep up traditions. On the other, they are confronted with the increasing pressures of consumerism and commercialization, which places the continuation of their cultural heritage in jeopardy.

The series of self-ironic studies presented the tragic choices of young Seto women as they find themselves at the crossroads of traditional and commercial cultures. The girls are faced with questions: how to react to the building of a new supermarket over an old cemetery or the use of Seto symbols to market goods and services that have little to do with traditional culture? To wear national costumes or not? As a refrain, the girls sing a mixture of traditional leelo songs and contemporary popmusic: "Super-Seto, Super-Seto, leelo, leelo", pointing sarcastically to the commercial requirement for all contemporary musical life to

41 Hot Estonian Guys 2018.

42 Eslas 2007. 
be dominated by its commodification, as Theodor Adorno puts it. ${ }^{43}$

How to Sell a Seto? left the impression of a Mayday call from a sinking ship. The production declared that commercialization and mass culture along with their tendency to fetishism, banal repetitions, and the "liquidation of the individual" 44 threaten to destroy the heritage and cultural continuity of old Estonia, which will be turned into a huge open air museum, a "non-place". ${ }^{45}$ Encouraged by successful performances, the troupe initiated two more productions, forming the Seto series. Using the theatrical public sphere to speak out their worries seemed to be a release for the young Setos.

By contrast, several years later, a bunch of productions started to speak in favour of globalization and anti-xenophobia. A documentary production, Smaller Inside than Outside (Endla Theatre, 2017), was undertaken by Mari-Liis Lill, an actress and stage director of socially relevant projects. The play was based on interviews with ordinary people, demonstrating the shortsightedness of radical national conservatism spreading in Estonian society. It revealed that people hostile to other cultures tend to be careless towards other minorities as well, even if they are their relatives or neighbors.

The topic of migration from the Third World was touched upon for the first time in another project of the same year, The Return of Furby at the Open Space (2017). This time, the approach was humorous. The troupe provided many creative solutions to the social problems in an age of migration, like decorating jars with Estonian national patterns and using them as protective covers in case of mosquitoes and cold weather, a necessary device during Nordic summers.

From another perspective, Apart: Estonians at Home and Abroad by Rakvere Theatre (2018) raised the issue of Estonians who had emigrated after World War II and had become the Others in the eyes of those who had remained. It insisted on the need to continue the communication, as "we are all Estonians".

\section{2) Estonian vs Russian communities}

The conflict of Estonian and Russian communities has a much longer history in Estonia, at the borderline of East and West. The present-day situation in Estonia is influenced by the last Russification of the Soviet period. In 1945, Estonians formed $94 \%$ of the population, by 1989 their share of the population had fallen to $61,5 \% .{ }^{46}$ Today, approximately a quarter of the Estonian population is Russianspeaking. Although the government has taken the approach of significant integration, the process has turned out more complicated than was expected. As a positive tendency, researchers have noted a process in the formation of a new ethno-cultural community, Estonian Russians. ${ }^{47}$ However, it is a well-known problem for sociologists and politicians that the two communities still tend to live in parallel worlds with different languages, customs, and political worldviews influenced by two oppositional media coverages. Against this background, young

43 Adorno 2006, 37.

44 Adorno 2006, 35.

45 Augé 1995.

46 O'Connor 2003, 128.

47 Kirch, Tuisk 2008. 
theatre makers have provided many anti-xenophobic productions that function as an integration project bringing two communities into one space - the theatre space.

The first show, At Second Sight (2016), was a rare cooperation project between Tallinn City Theatre and the Russian Theatre. It started with actors learning each other's language for two years. They made a production that started with an excursion around the capital, introducing landmarks which carry different connotations for Estonians and Russians. The show culminated on stage where two worldviews were opposed. Was Estonia occupied or freed by the Soviet Union in WWII? Is NATO a protective alliance or a threat? Should Russians learn Estonian - the official language that is hard to study and is spoken only by one million people? The show resulted with a scene describing the two communities engaging well on a practical level: two women discuss food recipes, sharing delicacies from Estonian and Russian cuisines.

While At Second Sight attempted to bring two audiences into one space, the next project, I'd Rather Dance with You (2016), went a step further, promoting dialogue between real people. The Vienna-based Russian choreographer and director Oleg Soulimenko came to Estonia with the experience of communication projects between Russian and Austrian artists. He started to examine the relationship of two nationalities in Estonia. In a talk show format, ordinary people were put on stage and members of the audience were invited to join their discussion. The whole night was covered with questions on political and social, cultural and personal issues: "Where do you get your news?", "Who are your friends?", "Tell me your biggest dreams", etc. The aim was not only to enhance dialogue between the conflicting worldviews, but to introduce fellow countrymen as people. Finally, a Russian and Estonian were asked to hug each other. It mostly succeeded.

The latest project by young documentary theatre authors Mari-Liis Lill and Paavo Piik aimed to be a mythbuster. For the project, Midsummer Day (Estonian Drama Theatre, 2018), they travelled to Siberia, $5000 \mathrm{~km}$ from Estonia. They researched the life of an old Estonian village that has been populated by expatriate Estonians and their descendants for more than a hundred years. Today, people there speak mostly Russian, watch Russian TV, praise Putin, but still consider themselves proudly as real Estonians with their distinctive culture. Thus, the notion of "real Estonian" was challenged and stereotypes of Estonians and Russians shifted, making Russian-speakers part of "us".

It is worthy of note that many integration productions have taken place at Open Space (Vaba Lava), the theatre center in Tallinn, that aims at changing mentalities in a wider scope. At the end of 2018, the center opened its branch in Narva, the eastern-most and third largest city in Estonia at the border with Russia. The region is known for industrialization, but also poverty, unemployment, abandoned properties, and a large Russian population (88\%). Thus the building of a new cultural venue in an old military factory aimed at integrating minorities through culture, creating a new community by regenerating places, and strengthening the identity of the local community as Russian-speaking Europeans, as stated 
by Kristiina Reidolv, the Managing Director of Open Space. ${ }^{48}$ The undertaking inspired the President of Estonia to relocate her entire Office to Narva for a period of one month in the autumn of 2018 to give more attention to the region, to break stereotypes, and to help establish civil society there. ${ }^{49}$

\section{3) e-Estonia vs Organic Estonia}

The discussion of two prevailing concepts of national identity forms one more facet of the scenic debate.

Firstly, there is a conception of e-Estonia as an advanced digital society that provides innovative services. It is a movement by the government of Estonia, presented as the success story of a tiny but innovative Nordic country, selfstyled as the most advanced digital society in the world, providing numerous e-services: i-Voting, e-Banking, e-Ticket, etc. Altogether $99 \%$ of public services are available online, saving the country 800 years of working time annually. ${ }^{50}$ In 2000, the Estonian government declared internet access as a human right. In 2014, Estonia became the first country to offer e-residency to non-Estonians, a step towards a digital nation of global citizens, "a country without borders", reminiscent of Benedict Anderson's idea of imagined communities. ${ }^{51}$

Secondly, the concept of Organic Estonia promotes traditional culture and untouched nature. It regards ancient forests and bogs as national symbols. The concept was the winner of an ideas competition held by the Estonian Development Fund in 2015 and aims at transforming Estonia into the first organic country in the world. Academics have emphasized that the idea does not cover only the economic dimension, but a free mental and spiritual environment, as well as a nation state and a traditional culture. ${ }^{52}$ The concept hints at geographic, historical, and ethnic nationalism as described by John Hutchinson and Anthony D. Smith. ${ }^{53}$

Both models enjoy their own home pages (e-estonia.com, organicestonia.ee) and recognition at state level, although the visions seem diametrically opposed if analyzed semiotically and with the help of the critical theory of the Frankfurt School.

The visual symbols of e-Estonia comprise mainly of digital and innovative elements: LEDs, skyscrapers, and mobile phones, all in futuristic tones of blue. A hand holding a phone seems to belong to a character from a computer game rather than a person of flesh and blood. Organic Estonia, in its turn, promotes itself with verdant forests, organic food, and children as the symbols of the bearers of cultural traditions - all in a very down-to-earth fashion. A conclusion by Adorno and Horkheimer seems especially telling in regard to these opposite concepts: "Men have always had to choose between their subjection to nature or the subjection of nature to the Self." 54

\footnotetext{
48 Reidolv 2018.

49 ERR News 2017.

50 E-Estonia 2018.

51 Anderson 2006.

52 Einasto 2017.

53 Hutchinson, Smith 2012, Smith 1991.

54 Adorno, Horkheimer 2016, 32.
} 
The characteristics of the two models can be presented in a comparison table of concepts:

\begin{tabular}{|c|c|}
\hline e-Estonia & Organic Estonia \\
\hline Forward-looking & Looking into the past \\
\hline Innovative technology & Ancient history and untouched nature \\
\hline Automated and digitalised & Band-made \\
\hline Based on rationality and logic & Local village \\
\hline Global village & Places (Augé) \\
\hline Non-places (Augé) & \\
\hline
\end{tabular}

However, for purposes of promotion, the two concepts are sometimes combined, e.g. "the smart and organic state", and called even a match made in heaven. ${ }^{55}$ Although the issue is rather new to humanitarian studies, a recent presentation offered a fused notion of an Estonian eco-digital narrative. ${ }^{56}$

Theatre projects have commented on the concepts from different points of view. For example, Three Kingdoms (2011) gave a valuable international commentary on Estonian identity. It was an innovative collaboration project between NO99, the Munich Kammerspiele, and the Lyric Hammersmith in London, premiering in all three countries. The play was spearheaded by UK dramatist Simon Stephens, German director Sebastian Nübling, and Estonian designer Ene-Liis Semper.

The cultural differences were depicted through a crime story that begins in the United Kingdom with the discovery of a woman's head. The English detectives follow the trail to Germany, where they come upon an East European sex trade ring leading to Tallinn. ${ }^{57}$ The show starts with a stable and peaceful situation in England: two detectives drink coffee and discuss musical preferences as one likes the Beatles, the other Chris Isaac. (Here, the audience can sense the cultural prejudices: "Englishmen are polite and haughty," stated Simon Stephens later. ${ }^{58}$ ) The further the detectives travel to the East, the more unpredictable the situations become, the more formless and hair-raising the environment turns, recalling the opposition of a "mature" Western and an "immature" Eastern Europe described by Polish philosopher Witold Gombrowicz. ${ }^{59}$

The project portrayed Estonia as an example of criminal Eastern Europe. At the same time, it was a wild, mystical, and mythical place, confronted by the anonymous non-places of Western and Central Europe. A character called Trickster suddenly intruded upon the scene and other characters wore deer or

55 Invest in Estonia 2018.

56 Annus 2018.

57 Balme 2014, 69.

58 Stephens 2011.

59 Gombrowicz 1998, 126-127. 
wolf headdresses, hinting at the concept of Organic Estonia.

The next two pieces signalled the utmost pessimism in future scenarios for Estonia. The Emigration Airfield (Tartu New Theatre, 2013) asked: will the last person to leave please turn out the lights? Spiced with black humor, the show presented the last remaining Estonians talking about their fellow countrymen as e-Ulysseses sailing on e-oceans. They complained about globalization, emigration, and the digital world distancing people. For example, in one episode, the detective Hercule Poirot is given such a difficult case to solve that he has to call other detectives for help: Sherlock Holmes, Miss Marple, Jules Maigret, and others. To them he explains:

"You ask - what is it all about? A whole nation is lost! [...] L'Estonie! A small lovely nation by the Baltic sea. [...] Now there is only an empty field. Like an airfield!"60

According to stage director Ivar Põllu, the show did not address only people who have physically left Estonia, as there are also many who have turned into "internal exiles" due to feeling redundant. They are equally lost to the state, to society and to the nation. ${ }^{61}$

The topical issue of emigration was also reflected in a documentary about Estonianness, 45,339 $\mathrm{km}^{2}$ of Bog in Endla Theatre (2015). The title referred to the total area of the country and one of the symbols of Organic Estonia, the wetland. The motto of the play was: "Should I stay or should I go?" The young team organized a survey among a thousand Estonians living abroad, asking about their reasons for departure, lifestyle and future plans. Out of the answers, a series of episodes were born. The stage director Laura Mets confessed she was dealing with the topic because the government does not. ${ }^{62}$ Out of one million ethnic Estonians, 200,000 have left the country in recent years.

It was a realistic look at the functioning of transnational Estonia, a concept introduced by the Human Development Report two years later. ${ }^{63}$ For example, the actors portrayed expatriate Estonians spending national holidays with the rest of the family by the help of Skype. The play showed the models of e-Estonia and Organic Estonia working together, although not as a match made in heaven, but in a more tragicomic manner arising from prosaic situations.

Finally, The Distinguishing Marks, a devised project by two video artists Chris Kondek and Christine Kühl from Berlin, performing at the Open Space (2017), tested the possibilities of e-residency. They voiced, for the first time on Estonian stages, criticism of the success story of e-Estonia. Christine Kühl cooled down the digital fanaticism of Estonians, describing how the automated, anonymous e-corridors and e-crossroads left her lonely and desperate. Her comments on an excessively rationalized and mechanized worldview resembled those of Adorno

60 Aas 2013, 28-29.

61 Eilat 2013.

62 Mets 2016.

63 Estonian Human Development Report 2016/2017. 
and Horkheimer. ${ }^{64}$

In conclusion, the theatre projects that discussed the two concepts of national identity unanimously supported Organic Estonia or its cooperation with e-Estonia. At the same time, they provided constructive criticism to the state-propagated e-Estonia model, that is hard to find in the mainstream media.

The discussion in the theatrical public sphere ranged from conservative nationalism to open nationalism and anti-xenophobia in a single decade (as presented on a timeline below), anticipating and complementing sociological studies in many ways. The projects became more frequent and provided indispensable insight, research, and analysis into the functioning of a modern nation state.

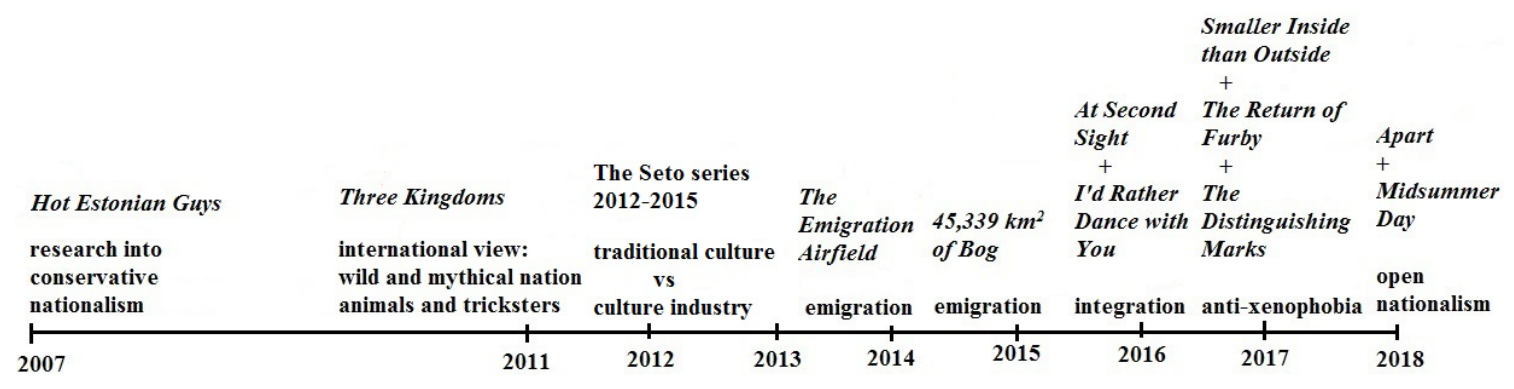

Timeline of the changing national mentality in the theatrical public sphere in Estonia, 2007-2018.

However different the social context and the character of the theatrical public sphere over several decades - the secret forum, the technical, or the agonistic public sphere -, it always created a mediating zone between the state and individuals. It enabled a discussion space with the possibility to affirm, protest, or voice opposition to dominant mentalities, thus supporting democratic developments. As seen in the examples above, on many occasions emotional and physical episodes, e.g. by NO99, expressed critical attitudes equal to rational-critical articulations. In doing so, the critical discussion was never simply a comment, a response, but an ongoing process. It opened up the possibility of practising new values and identifying new directions. Thus, the concept of public sphere has proved itself relevant to contemporary Estonian theatre as well as for theatre studies more generally.

\section{AUTHOR}

Eva-Liisa Linder is a theatre researcher at the Estonian Academy of Music and Theatre. She holds an MA in theatre studies from the University of Tartu and is a PhD student at Tallinn University School of Humanities, conducting research on the national stage in contemporary Estonia, in a comparative study of Estonian and European political theatre practices. As a freelance editor and critic, she has edited collections on theatre history and published several articles.

64 Adorno, Horkheimer 2016. 


\section{REFERENCES}

Aas, Mart. 2013. Äralennuväli. [The Emigration Airport.] Manuscript at the Estonian Theatre Agency.

Adorno, Theodor. 1997. "Cultural Criticism and Society." In Prisms. Translated by Samuel and Shierry Weber. Cambridge, 17-34.

Adorno, Theodor. 2006. The Culture Industry: Selected Essays on Mass Culture. London, New York: Routledge.

Adorno, Theodor; Max Horkheimer. 2016. Dialectic of Enlightenment. London: Verso.

Anderson, Benedict. 2006. Imagined Communities: Reflections on the Origin and Spread of Nationalism. London, New York: Verso.

Annus, Epp. 2018. "Aesthetic Sovietness: Vestigial Soviet-Era Landscapes in the Context of Estonia's High-Tech Dreams." International conference Contested Bodies: Identities and Spaces in the Post-Soviet Territories, University of Pennsylvania, Philadelphia, 15.-16.3.2018.

Augé, Marc. 1995. Non-Places. Introduction to an Anthropology of Supermodernity. Translated by John Howe. London, New York: Verso.

Balme, Christopher. 2012. "Public Sphere and Contemporary Performance." The IATC webjournal / Revue web de l'AICT, December (7). www.critical-stages.org/7/public-sphere-andcontemporary-performance (1.8.2018).

Balme, Christopher B. 2014. The Theatrical Public Sphere. UK: Cambridge University Press.

Carlson, Marvin. 2001. The Haunted Stage: the Theatre as Memory Machine. Ann Arbor: University of Michigan Press.

"E-governance." E-Estonia web page. www.e-estonia.com/solutions/e-governance/state-eservices-portal (1.5.2018).

Eilat, Taavi. 2013. "AK: Tartu Uue Teatri lavastus räägib Eestist lahkujatest." [The new production by Tartu New Theatre speaks of the ones leaving Estonia.] ERR, 29.11.2013. www.uusteater.ee/ tekstid/ak-tartu-uue-teatri-lavastus-raagib-eestist-lahkujatest (1.5.2018).

Einasto, Rein. 2017. "Mahe-Eestist rahvusriikluseni. Inimkesksusest ökosüsteemsuseni. Mõtisklusi." [From Organic Estonia to a nation state. From human-centredness to the ecosystems. Reflections.] Akadeemia, 7, 1155-1171.

Epner, Luule. 2005. "Redefining national identity by playing with classics." Sign System Studies, 33 (2), 379-404.

Eslas, Urve. 2007. "Sina! Tee lapsi!" [You! Make babies!] Postimees, 14.5. arvamus.postimees. ee/1660501/urve-eslas-sina-tee-lapsi (1.5.2018).

Estonian Human Development Report 2016/2017: Estonia at the Age of Migration. Cooperation 
Assembly Foundation. www.inimareng.ee/en (1.5.2018).

Gombrowicz, Witold. 1998. Päevaraamat. [Diary.] Translated by Hendrik Lindepuu. Vagabund, $126-127$.

Habermas, Jürgen. 1990. Strukturwandel der Öffentlichkeit: Untersuchungen zu einer Kategorie der bürgerlichen Gesellschaft. Mit einem Vorwort zur Neuauflage. Suhrkamp.

Habermas, Jürgen. 2001. "Philosophy in a Time of Terror." (An Interview with Giovanna Borradori.) The-Philosophy.com. www.the-philosophy.com/philosophy-time-terror-habermas (1.5.2018).

Hot Estonian Guys by Theatre NO99. no99.ee/productions/no88-gep-hot-estonian-guys (1.5.2018).

Hutchinson, John and Anthony D. Smith (eds). 2012. Nationalism. Oxford, New York: Oxford University Press.

Invest in Estonia. investinestonia.com/estonia-the-worlds-first-organic-country (1.5.2018).

"Kaljulaid, President's Office to relocate to Narva for one month next fall." ERR News, 28.12.2017. news.err.ee/651082/kaljulaid-president-s-office-to-relocate-to-narva-for-one-month-next-fall (1.8.2018).

Kase, Kajar. 2009. "Jänes jäi jänese-tükiga rahule.” [The Hare was satisfied with the hare-piece.] Postimees, 26.3. kultuur.postimees.ee/99246/janes-jai-janese-tukiga-rahule (1.5.2018).

Kirch, Aksel; Tuisk, Tarmo. 2008. "Estonians and Russians in Estonia: Is the Soviet Past Still Dominating the Present?" Proceedings of the Institute for European Studies, 4, International University Audentes, 67-94. www.ies.ee/iesp/No4/Kirch_Tuisk.pdf (1.8.2018).

Kivirähk, Juhan. 2016. Teatri positsioon ja roll ühiskonnas. [The position and role of theatre in society.] Eesti Etendusasutuste Liit, Eesti Teatriliit. www.eeteal.ee/sisu/326 1129Teatri Poisytsioon.pdf (1.5.2018).

Lauristin, Marju. 2011. "Kokkuvõtteks. Milline võiks olla Balti tee XXI sajandil." [Summary. The probable way of Baltics in XXI century.] In Eesti Inimarengu Aruanne 2011. Inimarengu Balti rajad: muutuste kaks aastakümmet. Tallinn: Eesti Koostöö Kogu, 192-200. kogu.ee/public/ eia2011/EIA_2011.pdf (1.5.2018).

Lehmann, Hans-Thies. 2006. Postdramatic Theatre. Translated and with an introduction by Karen Jürs-Munby. London, New York: Routledge.

Lehmann, Hans-Thies. 2007. "Theatre After Theatre." In Na(ar) Het Theater - After Theatre? Supplements to the International Conference on Postdramatic Theatre. Edited by Marijke Hoogenboom. Amsterdam School of the Arts Research Group, 47-55.

Linder, Eva-Liisa. 2013. "How Theatre Can Develop Democracy." Nordic Theatre Studies, 25, 84-96. 
Mets, Laura. 2016. Interview 16.3. Interviewed by Eva-Liisa Linder. The personal archive of EvaLiisa Linder.

Mouffe, Chantal. 2013. Agonistics: Thinking the World Politically. London: Verso.

O'Connor, Kevin. 2003. The History of the Baltic States. Connecticut, London: Greenwood Press.

Pesti, Madli. 2012. "Theatre Performance or Political Party?" Dialogi, 5-6.

Pilv, Aare. 2019. "Mis on NO99 moraal?" [What is the morality of NO99?] ERR Kultuur, 19.1. kultuur.err.ee/899991/aare-pilv-mis-on-no99-moraal (1.3.2019).

Põld, Anna. 2018. "Madison peab NO99 sulgemist konservatiivide töövõiduks." [Madison considers the closing of NO99 as an achievement of the conservatives.] Postimees, 31.10. www. postimees.ee/6442289/madison-peab-no99-sulgemist-konservatiivide-toovoiduks (1.3.2019).

Reidolv, Kristiina. 2018. "Theatre in Border Areas." Theatre and Migration, IFTR World Congress, Belgrade, 11.7.2018.

"Rein Lang: Teatrietenduse katkestamise süüdistus on laimukampaania!" [Rein Lang: The accusations in interrupting the performance are a smear campaign.] Eesti Ekspress, 26.3.2010. www.ekspress.delfi.ee/kuum/rein-lang-teatrietenduse-katkestamise-suudistus-onlaimukampaania?id=30042419 (1.5.2018).

"Rein Lang." Radar, 16.5.2015. www.youtube.com/watch?v=u7fydlbBzWo (1.5.2018).

Reinelt, Janelle. 2005. "National Signs: Estonian Identity in Performance." Sign System Studies, 33(2), 369-378.

Reinelt, Janelle. 2011. "Rethinking the Public Sphere for a Global Age." Performance Research, $16(2), 16-27$.

Reisenburg, Karel. 2017. "EKRE tahtis teatrilt NO99 riigi raha ära võtta: las Soros katab kulud." [Conservative People's Party of Estonia wanted to take state subsidies from NO99: let Soros cover the costs.] Postimees, 16.11. kultuur.postimees.ee/4312515/ekre-tahtis-teatrilt-no99-riigiraha-ara-votta-las-soros-katab-kulud (1.5.2018).

Rähesoo, Jaak. 2008. Estonian Theatre. Third Edition, Revised. Tallinn: Estonian Theatre Union.

Smith, Anthony D. 1991. National Identity. Reno, Las Vegas: University of Nevada Press.

Stephens, Simon. 2011. "Hüpata pimesi taevast alla ehk viis asja, mida ma olen õppinud Sebastian Nüblingilt." [To jump out of the window or five things I have learned from Sebastian Nübling.] Translated by Eero Epner. Sirp, 5.8. vana.no99.ee/tekstid.php?event_id=62\&nid=164 (1.5.2018).

Theatre NO99. 2018. "We finish." Theatre NO99, 31.10. no99.ee/en (31.10.2018).

"Ühtne Eesti Suurkogu." Unified Estonia Assembly video recording by Theatre NO99, 12.9.2013. 
$\underline{\text { www.youtube.com/watch?v=OAWXUVVh2I8 }}$ (1.5.2018).

Unified Estonia Assembly by Theatre N099. no99.ee/productions/no75-unified-estonia-assembly (1.5.2018).

"Unified Estonia in Prague." Unified Estonia web page by Theatre NO99, 12.6.2015. www. eestieest.ee/eesti-eest/uudised/unified-estonia-in-prague (1.5.2018).

Virro, Keiu. 2012. "NO99 projekt Ühtne Eesti - teatri ja poliitika piiridel." [The project Unified Estonia by NO99 - at the border of theatre and politics.] MA thesis in Cultural Theory, The Institute of Humanities at Tallinn University, Tallinn.

Wilmer, S. E. 2002. Theatre, Society and the Nation: Staging American Identities. Cambridge: Cambdrige University Press.

Wilmer, Stephen. 2009. "Theatrical Nationalism: Exposing the 'Obscene Superego' of the System." Journal of Dramatic Theory and Criticism, XXIII.2, Spring, 77-87.

Wilmer, Stephen. 2013. "The Added Value of Subversive Performance." International Conference Value Added of Contemporary Theatre: Who Needs Theatre Today?, Vilnius, 1.-2.10.2013. 